\title{
Reconceptualizing Establishment Clause Cases As Free Exercise Class Actions
}

\author{
Scott J. Ward
}

Few areas of Supreme Court jurisprudence have provoked as much commentary as the Court's decisions under the "establishment of religion" clause of the First Amendment. ${ }^{1}$ One increasingly influential school of thought critical of the Court's establishment clause doctrine argues that the establishment clause is the complement of the free exercise clause $^{2}$ - that the establishment clause, like the free exercise clause, is a guarantee of religious liberty; that the establishment clause, like the free exercise clause, should focus on governmental coercion affecting religious choice. ${ }^{3}$

This view is promising: it makes more sense of the text, history, and current doctrine (to the extent salvageable) of the establishment clause than any other offered so far. But it also presents troubling implications. What does the establishment clause provide that the free exercise clause does not, if a claim can be conceptualized under either clause? Does this view, in its attempt to reconcile and harmonize the two clauses, improperly collapse them into each other?"

One possible answer is that the two clauses should essentially be treated as one. ${ }^{5}$ But another answer is that the establishment clause, functionally, is a "public law" analogue to the free exercise clause-a "class action" version of the free exercise clause. This Note suggests that courts should analogize the establishment clause to a "class action" aggregation of free exercise claims in its protection of religious liberty. Because individual religious liberty interests are generally smaller in establishment clause cases than in free exercise cases, the establishment clause protects free

1. "Congress shall make no law respecting an establishment of religion." U.S. ConsT. amend. I, cl. 1 .

2. "Congress shall make no law ... prohibiting the free exercise [of religion]." U.S. ConST. amend. I, cl. 2.

3. See McConnell, Accommodation of Religion, 1985 SuP. CT. REv. 1 [hereinafter McConnell, Accommodation]; McConnell, Coercion: The Lost Element of Establishment, 27 WM. \& MARY L. REv. 933 (1986) [hereinafter McConnell, Coercion]; Paulsen, Religion, Equality, and the Constitution: An Equal Protection Approach to Establishment Clause Adjudication, 61 NOTRE DAME L. REv. 311 (1986).

4. See G. Stone, L. Seidman, C. Sunstein \& M. Tushnet, Constitutional Law 188 (Supp. 1988).

5. See Paulsen, supra note 3 (suggesting that establishment clause requires "equal protection" of the free exercise of religion). 
exercise interests that tend to be undervindicated by the use of a simple bipolar litigation model, where the incentive for any individual to bring suit is diminished. On the other hand, establishment clause claims, as currently adjudicated, tend to overstate the extent of the constitutional violation and resulting harm. The relief granted tends to be broader than necessary to remedy the injury suffered, violating the principle that the scope of the remedy must be narrowly tailored to the nature and extent of the constitutional violation. $^{\mathbf{B}}$

This Note examines the possibility of reconceptualizing establishment clause cases as class action aggregations of free exercise interests. Section I briefly discusses the origins and shortcomings of the Court's existing establishment clause jurisprudence, and argues for an analysis that focuses upon religious liberty. Section II describes a possible free exercise-class action approach based upon the coercion of religious choice created by a challenged government action. Section III examines the implications of this mode of analysis, with particular regard to standing to sue and remedial possibilities.

\section{Establishment Glause Jurisprudence and Its Problems}

Since the establishment clause was first applied to the states in 1947, ${ }^{7}$ the Supreme Court has struggled to give meaning to that provision within the twentieth century context. The Court has from the outset of this enterprise relied upon the historical foundations of the clause to guide its interpretations..$^{8}$ In Everson, the Court relied on the writings of Thomas Jefferson and James Madison as interpretive aids in concluding that the clause creates, in Jefferson's phrase, "a wall of separation between church and State;"' this reading of history formed the basis of the Court's early establishment clause decisions. ${ }^{10}$

6. See, e.g., General Bldg. Contractors Ass'n, Inc. v. Pennsylvania, 458 U.S. 375, 399 (1982); Dayton Bd. of Educ. v. Brinkman, 433 U.S. 406, 419-20 (1977).

7. Everson v. Board of Educ., 330 U.S. 1 (1947) (upholding state provision of bus transportation for parochial and non-parochial school students).

8. See Everson, 330 U.S. 1, 8-16; id. at 33 (Rutledge, J., dissenting); see also Lynch v. Donnelly, 465 U.S. 668 (1984) (historical acceptance of crèche displays); Marsh v. Chambers, 463 U.S. 783 (1983) (historical acceptance of legislative invocations).

9. See Everson, 330 U.S. at 15-16 (quoting letter from Thomas Jefferson to Committee of the Danbury Baptist Ass'n (Jan. 1, 1802), reprinted in 16 The Writings of Thomas Jefferson 281-82 (A. Bergh ed. 1907)).

10. This Note's utilization of historical arguments is in response to the Supreme Court's perception that the meaning of the establishment clause is singularly discernible in that clause's unique history. Space limitations prevent a thorough discussion here of methods of constitutional interpretation. Suffice it to say that this Note's methodology is "interpretivist" in that it accords constitutional text, structure, and history a guiding role in interpretation while rejecting the claim that the specific "original intentions" of the Framers are clear as a matter of history and binding as a matter of constitutional law. See generally Powell, Rules for Originalists, 73 VA. L. Rev. 659, 695 (1987) ("Our distance from the founders makes translation necessary; what we have in common with them makes translation worthwhile."). 


\section{A. Historical and Doctrinal Difficulties}

Numerous critics have argued that the Court's initial historical analysis was severely flawed. ${ }^{11}$ As it has become evident that the historical foundations of the clause are more complex than the Court's historical account suggests, the Court has shifted from historical analysis to doctrinal development, ${ }^{12}$ ultimately summarizing this development in a three part test announced in Lemon v. Kurtzman: ${ }^{13}$ the challenged state action must have a legitimate secular purpose, its primary effect must be neither to advance nor to inhibit religion, and it must not create excessive entanglement between the state and religious entities. ${ }^{14}$

The Supreme Court's characterization of the history and meaning of the establishment clause has been a source of significant controversy. ${ }^{15}$ The Court's doctrinal approach to the establishment clause has been subject to criticism on two main grounds. First, it has created an unnatural tension between the establishment clause and the free exercise clause. ${ }^{16}$ The Justices have found that an accommodation of religion required by the free exercise clause may be, when enacted into law, an impermissible violation of the establishment clause. ${ }^{17}$ When it has acknowledged this

11. See, e.g., Wallace v. Jaffree, 472 U.S. 38, 91-114 (1985) (Rehnquist, J., dissenting); R. Cord, Separation of Church and State: Historical Fact and Current Fiction (1982); M. Malbin, Religion and Politics: The Intentions of the Authors of the First AmendMENT (1978); McConnell, Coercion, supra note 3; Smith, Getting Off On the Wrong Foot and Back On Again: A Reexamination of the History of the Framing of the Religion Clauses of the First Amendment and a Critique of the Reynolds and Everson Decisions, 20 WAkE Forest L. Rev. 569 (1984); see also Flast v. Cohen, 392 U.S. 83, 125-26 (1968) (Harlan, J., dissenting) ("the historical purposes of the religious clauses of the First Amendment are significantly more obscure and complex than this Court has heretofore acknowledged."); Kurland, The Origins of the Religion Clauses of the Constitution, 27 WM. \& MARY L. REv. 839, 841-42 (1986) ("History should provide the perimeters within which the choice of meaning may be made. History ordinarily should not be expected, however, to provide specific answers to the specific problems that bedevil the Court.").

12. While the Supreme Court has shifted from relying upon history to relying upon doctrine and precedent, the Court has based its doctrinal development upon precedents that were themselves justified on the basis of the Court's reading of history. See McConnell, Coercion, supra note 3, at 934 ("Essentially, what once was declared necessary because of history now is declared necessary because of precedent.").

13. 403 U.S. 602 (1971).

14. Lemon, 403 U.S. at $612-13$. The Court has indicated an unwillingness to be confined to this single test, see Lynch v. Donnelly, 465 U.S. 668, 679 (1984); Committee for Public Educ. v. Nyquist, 413 U.S. 756, 773 n.31 (1973); Tilton v. Richardson, 403 U.S. 672, 677-78 (1971), and has not uniformly applied the test, see Lynch, 465 U.S. 668 (historical test for crèche display); Marsh v. Chambers, 463 U.S. 783 (1983) (historical test for legislative prayer); Larson v. Valente, 456 U.S. 228 (1982) (strict scrutiny test for regulation alleged to discriminate among religious organizations).

15. See Smith, The Special Place of Religion in the Constitution, 1983 Sup. CT. Rev. 83, 97-98.

16. See, e.g., L. TRIBE, American Constitutional Law $\$ 14-1$, at 1154 (2d ed. 1988); Nichol, Introduction: Religion and the State, 27 WM. \& MARY L. REv. 833, 835-36 (1986); Pfeffer, Freedom and/or Separation: The Constitutional Dilemma of the First Amendment, 64 MinN. L. REv. 561 (1980); Symposium: The Tension Between the Free Exercise Clause and the Establishment Clause of the First Amendment, 47 Oнiо ST. L.J. 289, 289-499 (1986).

17. Compare Sherbert v. Verner, 374 U.S. 398 (1963) (denial of unemployment benefits to Seventh Day Adventist due to refusal to accept employment requiring Saturday work impermissibly burdens free exercise) with Estate of Thornton v. Caldor, Inc., 472 U.S. 703 (1985) (state law protecting workers from dismissal for refusing to work on chosen Sabbath impermissibly advances religion); see also McConnell, Accommodation, supra note 3. 
tension, the Court has portrayed it as inherent in the two clauses and not as the product of errant constructions of them. ${ }^{18}$ Second, the Court, recognizing the dissonance between its doctrine and the textual and historical background of the clause, has at times declined to apply the Lemon test, ${ }^{19}$ or has been less than rigorous in its application. ${ }^{20}$ The Court's holdings under its establishment clause doctrine therefore have struck many observers as inconsistent and unprincipled. ${ }^{21}$ The Gourt itself admits that the Lemon test "sacrifices clarity and predictability for flexibility;" 22 this seems to some a tacit admission that the Court's actual approach to an establishment clause violation is one of "we know it when we see it."

\section{B. The Lost Element of Establishment}

In 1789, the framers of the First Amendment were concerned primarily with limiting the power of the new Federal government with regard to religion in the states. ${ }^{24}$ This dimension has been undermined by the incor-

18. "The Court has struggled to find a neutral course between the two Religion Clauses, both of which are cast in absolute terms, and either of which, if expanded to a logical extreme, would tend to clash with the other." Walz v. Tax Comm'n, 397 U.S. 664, 668-69 (1970). This "neutral course" has struck one dissenter as one "narrow[ing] the channel between the Scylla and Charybdis. . .." Thomas v. Review Bd., 450 U.S. 707, 721 (1981) (Rehnquist, J., dissenting).

19. See, e.g., Marsh v. Chambers, 463 U.S. 783 (1983) (applying historical test, rather than Lemon test, to evaluate legislative prayer).

20. See, e.g., Lynch v. Donnelly, 465 U.S. 668 (1984) (municipally-sponsored nativity scene does not violate establishment clause).

21. See, e.g., Edwards v. Aguillard, 482 U.S. 578, 636 (1987) (Scalia, J., dissenting); Wallace v. Jaffree, 472 U.S. 38, 110-11 (1985) (Rehnquist, J., dissenting); Choper, The Religion Clauses of the First Amendment: Reconciling the Conflict, 41 U. PITT. L. REv. 673, 680-81 (1980); Marshall, Unprecedential Analysis and Original Intent, 27 WM. \& MARY L. Rev. 925, 926 (1986); Paulsen, supra note 3, at 315-17.

22. Committee for Public Educ. v. Regan, 444 U.S. 646, 662 (1980). The Lemon test has come under criticism from four members of the Court, see Corporation of Presiding Bishop v. Amos, 483 U.S. 327, 346-49 (1987) (O'Connor, J., concurring); Aguillard, 482 U.S. at 613-19 (Scalia, J., dissenting); Jaffree, 472 U.S. at 91 (White, J., dissenting); id. at 91-114 (Rehnquist, J., dissenting), but it remains the standard, see Bowen v. Kendrick, 108 S. Ct. 2562, 2570 (1988).

23. Marshall, "We Know It When We See It": The Supreme Court and Establishment, $59 \mathrm{~S}$. CAL. L. Rev. 495 (1986).

24.

As a matter of history, the First Amendment was adopted solely as a limitation upon the newly created National Government. The events leading to its adoption strongly suggest that the Establishment Clause was primarily an attempt to insure that Congress not only would be powerless to establish a national church, but would also be unable to interfere with existing state establishments.

Abington School Dist. v. Schempp, 374 U.S. 203, 309-10 (1963) (Stewart, J., dissenting); see also id. at 253 (Brennan, J, concurring) ("No one questions that the Framers of the First Amendment intended to restrict exclusively the powers of the Federal Government"); McGowan v. Maryland, 366 U.S. 420, 440-41 (1961); M. Howe, The Garden and the Wilderness: Religion and GovERNMENT IN AMERICAN CONSTITUTIONAL History 3, 172 (1965); L. Levy, The Establishment Clause: Religion and The First Amendment 63-89 (1986); M. Malbin, supra note 11, at 3-17; Kurland, supra note 11, at 843-44. Madison's original proposal for what eventually became the religion clauses of the First Amendment would have prohibited both the national and state governments from violating the equal rights of conscience. See 1 ANNALs OF CoNG. 452 (J. Gales ed. 1834) (June 8,1789 ). Because the calls for a bill of rights had been motivated almost exclusively by a fear of the power of the new national government, however, most Congressmen thought that limitations on state power were beyond the scope of the desired amendments. See Kurland, supra note 11, at 
poration of the establishment clause to apply to the states through the due process clause of the Fourteenth Amendment. The Court incorporated the establishment clause with a single paragraph of discussion in Everson, ${ }^{25}$ citing only its decisions in Cantwell $v$. Connecticut ${ }^{26}$ and Watson $v$. Jones. ${ }^{27}$ Obviously, a provision designed primarily to protect the states from federal interference does not incorporate well as a limitation upon state power. ${ }^{28}$ What, then, remains of the establishment clause after it is interpreted to apply as a limitation against the states?

The Supreme Court's answer has been "Quite a bit."29 The Court has extended the establishment clause beyond the protection of religious liberty provided by the free exercise clause. Downplaying the religious liberty component of the establishment clause, the Court has suggested that violations of that clause do not require the presence of religious coercion. ${ }^{30}$ Instead, the Lemon test considers other factors, leading the Court to strike down government actions that are motivated primarily by a religious purpose, ${ }^{31}$ whose primary effect is to advance religion, ${ }^{32}$ or that create a risk of "excessive entanglement" between church and state. ${ }^{33}$ The Court's dependence upon its historical definition of the establishment clause has discouraged it from undertaking a thorough analysis of the various interests

857-58. Moreover, most state constitutions in 1789 contained some guarantee of religious liberty. See B. Schwartz, The Great Rights of MaNkind 87-89 (1977).

25. 330 U.S. 1,15 (1947).

26. 310 U.S. 296 (1940) (free exercise clause incorporated through the Fourteenth Amendment).

27. 80 U.S. (13 Wall.) 679,730 (1871) (free exercise and establishment clauses interrelated).

28. Abington, 374 U.S. at 310 (Stewart, J., dissenting) ("it is not without irony that a constitutional provision evidently designed to leave the States free to go their own way should now have become a restriction upon their autonomy."). In this respect, incorporating the establishment clause makes about as much sense as incorporating other federalism provisions of the bill of rights, such as the Ninth or Tenth Amendments. See Paulsen, supra note 3, at 317 \& n.38.

29. Some commentators have answered: "Nothing." That is, the liberty protected by the Fourteenth Amendment cannot incorporate the establishment clause because it is not a Bill of Rights provision that explicitly protects individual liberties. See, e.g., E. CoRwIN, A Constrrutron of Powers in a Secular State 114 (1951) ("So far as the Fourteenth Amendment is concerned, States are entirely free to establish religions, provided they do not deprive anybody of religious liberty."). One answer to this contention "is that it underestimates the role of the Establishment Clause as a coguarantor, with the Free Exercise Clause, of religious liberty. The Framers did not entrust the liberty of religious beliefs to either clause alone." Abington, 374 U.S. at 256 (Brennan, J., concurring). Although incorporation in general, and incorporation of the establishment clause in particular, have been the objects of criticism, there can be little doubt that incorporation of the establishment clause is a fait accompli, regardless of its historical verity. Abington, 374 U.S. at 217 ("Such contentions [that incorporation of the establishment clause is incorrect], in the light of the consistent interpretation in cases of this court, seem entirely untenable and of value only as academic exercises."); Kurland, The Irrelevance of the Constitution: The Religion Clauses of the First Amendment and the Supreme Court, 24 VILL. L. REv. 3, 11 (1978).

30. See infra notes $37-51$ and accompanying text.

31. See, e.g., Edwards v. Aguillard, 482 U.S. 578 (1987) (invalidating statute requiring "balanced treatment" in public school science classes of evolutionism and "creation science"). The Court's holding was premised on its finding that the statute's primary purpose was religious. See id. at 594.

32. See, e.g., Grand Rapids School Dist. v. Ball, 473 U.S. 373 (1985) (municipal provision of secular classes in religious schools impermissibly advances religion).

33. See, e.g., Aguilar v. Felton, 473 U.S. 402 (1985) (mechanisms for ensuring that federal financial aid to provide remedial education in nonpublic schools does not advance religion create excessive entanglement of state in religious affairs). 
(particularly individual religious liberty interests) involved in these cases. ${ }^{34}$ Moreover, in applying the clause to the states, the Court has enlarged its scope to invalidate government activities that were not found unconstitutional at the federal level before incorporation. ${ }^{38}$

The historical evidence, however, suggests that, federal-state issues aside, the primary concern of the establishment clause is the protection of religious liberty ${ }^{36}$ Many commentators who have addressed this situation have suggested that the two clauses should be read as complementary ${ }^{37}$ Although the specific content of these suggestions has varied, the history and text support reading both clauses as concerned with the protection of religious liberty. Some proponents of this interpretation suggest that, contrary to Supreme Court dicta in Engel v. Vitale ${ }^{38}$ and Abington School Dist. v. Schempp, ${ }^{38}$ coercion of religious belief, choice, or exercise is the essence of an establishment clause violation, as it is of a free exercise clause infraction. ${ }^{40}$ This position avoids creating tension between the two

34. Cf. Nowak, Due Process Methodology in the Post-Incorporation World, 70 J. CRIM. L. \& Criminology 397, 400-01 (1979) (arguing that attempts to base all criminal procedure decisions on specific guarantees of the Bill of Rights tend to rely on definitional analysis and therefore fail to explore the interests at stake).

35. Paulsen, supra note 3, at 323. Professor Howe has noted that, ironically, the difficulties in interpreting the establishment clause (particularly the tension with free exercise) following Everson are the result of a departure from precedent. In Cantwell v. Connecticut, 310 U.S. 296 (1940), the first case incorporating the religion clauses, the Court interpreted the establishment clause as:

something far less radical than a banning of all forms of aid to religion. The prohibition was read merely as a ban on a particular species of infringement of religious liberty. Given that restrictive meaning, there were, of course, no logical difficulties in the Court's assumption that

the liberties secured by the Fourteenth Amendment included each variety of religious liberty. M. Howe, supra note 24, at 108.

36. From the American Revolution until the ratification of the First Amendment, arguments in favor of limiting the powers of the state or national governments regarding religious establishments were generally phrased in terms of religious liberty. See T. CURRY, The First Freedoms: ChuRCH and State in America to the Passage of the First Amendment 146, 210-17 (1986). Indeed, the entire argument of James Madison's Memorial and Remonstrance Against Religious Assessments is concerned with the negative impact of Virginia's General Assessment bill on religious liberty. Madison, Memorial and Remonstrance Against Religious Assessments (circa June 20, 1785), reprinted in 8 The Papers of James Madison 298, 300 (R. Rutland \& W. Rachal eds. 1973) [hereinafter Madison, Remonstrance].

37. E.g., M. Howe, supra note 24, at 108; L. Pfeffer, Church, State, and Freedom 122 (1953); Choper, supra note 21, at 677; Dunsford, The Establishment Syndrome and Religious Liberty, 2 DuQ. L. Rev. 139, 203-12 (1953); McConnell, Neutrality Under the Religion Clauses, 81 Nw. U.L. REv. 146, 148-49 (1986); Moore, The Supreme Court and the Relationship Between the "Establishment" and "Free Exercise" Clauses, 42 TEx. L.Rev. 142, 196 (1963); Paulsen, supra note 3; see also Abington, 374 U.S. at 232 (Brennan, J., concurring) ("the Framers . . . were not content to rest the protection of religious liberty exclusively upon either clause."). Cf. Kurland, of Church and State and the Supreme Court, 29 U. CHI. L. REv. 1, 4-6 (1961) (establishment and free exercise clauses, in conjunction, prohibit classification in terms of religion, either to confer benefit or to impose burden).

38. 370 U.S. 421,430 (1962) ("The Establishment Clause, unlike the Free Exercise Clause, does not depend upon any showing of direct governmental compulsion and is violated by the enactment of laws which establish an official religion whether those laws operate directly to coerce nonobserving individuals or not.").

39. 374 U.S. 203, 223 (1963) ("The distinction between the two clauses is apparent-a violation of the Free Exercise Clause is predicated on coercion while the Establishment Clause violation need not be so attended.").

40. See McConnell, Coercion, supra note 3, at 934-37; Paulsen, supra note 3, at 313. 
clauses, but recognizing that the principal objective of the establishment clause is the protection of religious liberty does not explain how the clause operates to protect the freedom of religious choice.

\section{A Free Exercise-Class Action Approach}

\section{A. Adjudicating A Free Exercise Class Suit}

The Supreme Court has established a two-step test to determine when a free exercise exemption ${ }^{41}$ should be granted. First, a plaintiff must demonstrate that the challenged governmental conduct burdens a sincerely-held religious belief. ${ }^{42}$ Once a plaintiff has satisfied this requirement, the government must demonstrate that its rule is the least restrictive means to achieve a compelling state end. ${ }^{43}$ If the state fails to carry this burden, the plaintiff receives an exemption. ${ }^{44}$

The fundamental premise of modern free exercise jurisprudence is that the state may only coerce an individual's religious exercise when its actions are "essential to accomplish an overriding governmental interest." In the context of the activist regulatory state, this not only means that the government may not prohibit religious conduct, but also that it may not deny an otherwise available benefit on the basis of religion. ${ }^{46}$

The Supreme Court has at times recognized that a similar concern underlay the 'framing of the establishment clause. In Cantwell $v$. Connecti$c u t$, the first case applying the religion clauses to the states, the Court stated that the establishment clause was intended primarily to protect religious liberty by "forestall[ing] compulsion by law of the acceptance of any creed or the practice of any form of worship." ${ }^{\prime 27}$ The Court has also made reference to this element of compulsion in several establishment clause cases. ${ }^{48}$ But despite the Court's occasional recognition of the historical centrality of religious coercion to both clauses, ${ }^{49}$ the Lemon test does not

41. An exemption excuses a claimant from the requirements of the challenged (facially neutral) law that burdens religious freedom. See, e.g., Thomas v. Review Bd., 450 U.S. 707 (1981) (exemption from state eligibility rule for unemployment benefits for person whose resignation was mandated by religious beliefs).

42. Although the truth of a belief may not be examined, it must be "truly held." United States v. Seeger, 380 U.S. 163, 185 (1965).

43. Thomas, 450 U.S. at 718 . This inquiry focuses upon the state's interest in denying an exemption, not the interest in maintaining the underlying rule for unexceptional cases. L. Tribe, AMERICAN Constitutional Law $\$ 14-10$, at 855 (1st ed. 1978).

44. See, e.g., Hobbie v. Unemployment Appeals Comm'n, 480 U.S. 136 (1987); United States v. Lee, 455 U.S. 252 (1983); Thomas, 450 U.S. 707; Sherbert v. Verner, 374 U.S. 398 (1963).

45. Lee, 455 U.S. at 257-58.

46. Thomas, 450 U.S. at $717-18$. This approach was initially employed in Sherbert, 374 U.S. at 398.

47. 310 U.S. 296,303 (1940).

48. See McGowan v. Maryland, 366 U.S. 420, 451-52 (1961); Zorach v. Clauson, 343 U.S. 306, 309-12 (1952); McCollum v. Board of Educ., 333 U.S. 203, 314 (1948); see also McConnell, Coercion, supra note 3 , at $934-35$.

49. "[T]he Court has identified the individual's freedom of conscience as the central liberty that unifies the various clauses in the First Amendment." Wallace v. Jaffree, 472 U.S. 38, 50 (1985); see 
explicitly consider such coercion. ${ }^{50} \mathrm{~A}$ free exercise-class action approach to the establishment clause would focus precisely upon this issue. ${ }^{81}$

\section{B. A Taxonomy of Coercion}

The attempt to define the establishment clause in terms of coercion is complicated by the fact that the Supreme Court's views of coercion under the two religion clauses have not been symmetrical. Despite the Court's contention that establishment clause violations do not necessarily involve coercion of religious choice, ${ }^{\mathbf{S 2}}$ more than once it has noted the presence of religious coercion in striking down a practice under that clause. ${ }^{53}$ The failure to identify coercion as the central element of establishment has prevented the Court from analyzing how various types of conduct challenged under the establishment clause act to coerce religious choice.

\section{Coerced Religious Practices}

At the heart of the religious liberty guaranteed by the First Amendment is the protection from being required to act contrary to one's religious convictions. Governmental compulsion of religiously objectionable conduct and prohibition of religiously motivated conduct were the primary evils with which the framers of the religion clauses were concerned. ${ }^{54}$ Modern variations of this type of compulsion include a state requirement that license plates display the motto "Live Free or Die" applied to a religious

McConnell, Coercion, supra note 3.

50. See Lemon v. Kurtzman, 403 U.S. 602, 612-13 (1971).

51. A free exercise suit may be brought as a class action in federal court under Rule 23 of the Federal Rules of Civil Procedure. FED. R. Grv. P. 23. In order to be maintained as a class action, a suit must first satisfy the four requirements of Rule 23(a): (1) the class is too numerous for practicable joinder of all members; (2) there are questions of law or fact common to the class; (3) the claims of the representative parties are typical of those of the class; and (4) the representatives will adequately protect the interests of the class. Most establishment clause cases brought as free exercise class suits would satisfy these requirements.

Free exercise claims for class relief are rarely made because such claims would expose the basic weakness of free exercise exemptions: the impact that exemptions to all those similarly situated to the plaintiff would have on the challenged rule. Such a suit ceases to be a request for an individual exemption and becomes an attack on the regulation itself. $C$. Mozert v. Hawkins County Bd. of Educ., 827 F.2d 1058, 1072-73 (6th Cir. 1987) (Kennedy, J., concurring), cert. denied, 108 S. Ct. 1029 (1988) (noting negative impact on public school reading curriculum of allowing widespread exemptions); Wilder v. Bernstein, 499 F. Supp. 980 (S.D.N.Y. 1980) (free exercise challenge to Gatholic foster care agency regulations prohibiting birth control information).

52. See Engel, 370 U.S. at 430; Abington, 374 U.S. at 223.

53. See, e.g., Engel, 370 U.S. at 429-30; Everson v. Board of Educ., 330 U.S. 1, 8-11 (1947).

54. For example, in colonial Virginia, preaching or holding a religious meeting other than as prescribed by Anglican liturgy and practice was punishable by criminal sanctions. See L. LEvY, supra note 24, at 1-5; Letter from James Madison to William Bradford (Jan. 24, 1774), reprinted in 1 The Papers of James Madison 104, 106 (R. Rutland \& W. Rachal eds. 1973). The legislative history behind the drafting of the First Amendment indicates that the Amendment was intended to prohibit the federal government both from prohibiting such religious exercises and from compelling any form of religious observance. See 1 ANNals of CoNG. 730-31 (J. Gales ed. 1834) (Aug. 15, 1789); Kurland, supra note 11. 
objector, ${ }^{\mathrm{bs}}$ a mandatory religious oath as a prerequisite to holding a state office, ${ }^{56}$ or the recitation of the Pledge of Allegiance as a condition of attendance at public school. ${ }^{57}$ These forms of coercion are traditionally and invariably cognizable under the free exercise clause. ${ }^{58}$

\section{Inequality of Benefits}

In the twentieth century, the Court has recognized that coercion may take more subtle forms, particularly in the modern welfare state. ${ }^{58}$

Where the state conditions receipt of an important benefit upon conduct proscribed by a religious faith, or where it denies such a benefit because of conduct mandated by religious belief, thereby putting substantial pressure on an adherent to modify his behavior and to violate his beliefs, a burden upon religion exists. While the compulsion may be indirect, the infringement upon free exercise is nonetheless substantial. ${ }^{60}$

Where one entity receives a public benefit while another similarly situated does not, religious coercion is again present. In essence, the state is engaging in a form of bribery or blackmail by creating strong incentives in favor of one form of religious exercise and against another through its distribution of welfare entitlements. ${ }^{\text {B1 }}$

These forms of coercion are the subject of litigation under both religion clauses. ${ }^{62}$ It is in this area that the two clauses most often seem to collide. This collision, which is most apparent when the Court is reviewing a governmental effort to accommodate religion, may be the inevitable result of the Lemon test's failure to focus upon coercion. ${ }^{63}$ The practical difficul-

55. Wooley v. Maynard, 430 U.S. 705 (1977).

56. Torcaso v. Watkins, 367 U.S. 488 (1961).

57. West Virginia State Bd. of Educ. v. Barnette, 319 U.S. 624 (1943).

58. See supra notes $42-46$ and accompanying text.

59. "The rise of the welfare state was not the fall of the Free Exercise Clause." Bowen v. Roy, 476 U.S. 693, 732 (1986) (O'Connor, J., concurring and dissenting).

60. Thomas v. Review Bd., 450 U.S. 707, 717-18 (1981). This approach was initially employed in Sherbert v. Verner, 374 U.S. 398 (1963).

61. See, e.g, Hobbie v. Unemployment Appeals Comm'n, 480 U.S. 136 (1987); Thomas, 450 U.S. 707; Sherbert, 374 U. S. 398; cf. Madison, Remonstrance, supra note 36, at 300 ("As the [General Assessment] Bill violates equality by subjecting some to peculiar burdens, so it violates the same principle, by granting to others peculiar exemptions.").

A similar concern for the influence of unequal treatment compromising religious choice at the hands of the law underlies the Supreme Court's decision in Larson v. Valente, 456 U.S. 288 (1982). Larson is significant because it was an establishment clause case in which the Court did not apply the Lemon test, but rather used a strict scrutiny test similar to the test employed under the free exercise clause. The Court found that a state charitable solicitations act, which exempted from reporting requirements only religious organizations obtaining more than fifty percent of their total contributions from members or affiliated organizations, discriminated among religions, and was not the least burdensome means of achieving a compelling state interest.

62. See, e.g., Larson, 456 U.S. 288 (establishment clause); Thomas v. Review Bd., 450 U.S. 707

(1981) (free exercise clause).

63. See generally McConnell, Accommodation, supra note 3. 
ties of distinguishing government efforts to accommodate religious beliefs from governmental attempts to advance religious positions lead inexorably to this conflict. $^{64}$

\section{Threat of Stigmatization}

The Court has also recognized the stigma that might be suffered by individuals forced to "opt out" activity. ${ }^{66}$ The Gourt has noted such stigmatization in striking down statesponsored religious practices that provide for excusing or exempting dissenters $^{67}$ (particularly dissenting public schoolchildren ${ }^{68}$ ). Stigmatization is essentially a weaker form of governmental compulsion, where the government creates social pressures that lead individuals to undertake conduct that the state could not (and may not intend to) compel directly.

Despite recognizing the coercive threat of stigmatization in the establishment clause context, ${ }^{69}$ the Court has failed to note any such danger in free exercise cases. Indeed, the option of being excused from participation in an objectionable practice, which raises the specter of stigmatization in establishment clause cases, is the very mechanism usually employed as a remedy under the free exercise clause. ${ }^{70}$ This is significant because the coercive impact of stigmatization upon individuals does not vary depending upon whether the public practice from which exemption is sought is labelled "religious," as seems to be the implicit premise supporting the Court's differing approaches under the two clauses.

\section{Government Endorsement}

A fourth form of coercion of religious choice might arise from the state endorsing particular religious beliefs, symbols, or practices. The Court has

64. The government has ample room to accommodate religious practices, Walz v. Tax Comm'n, 397 U.S. 664,673 (1970), but, at some point, accommodation may devolve into unlawful fostering of religion, Hobbie v. Unemployment Appeals Comm'n, 480 U.S. 136, 145 (1987).

65. Opt-out provisions may be part of the challenged practice, see, e.g., Engel v. Vitale, 370 U.S. 421, 438-39 (1962) (Douglas, J., concurring), or may be available only as a judicially-imposed remedy following a lawsuit, see, e.g., West Virginia State Bd. of Educ. v. Barnette, 319 U.S. 624 (1943).

66. See, e.g., Jaffree, 472 U.S. 38 (state statute requiring moment of silence at beginning of school day, with specific provision for "voluntary prayer"); Abington School Dist. v. Schempp, 374 U.S. 203 (1963) (state statute requiring reading of Biblical passages at beginning of school day); Engel v. Vitale, 370 U.S. 421 (1962) (state-sponsored teacher-led prayer in public school classrooms). The form of the opt-out provision can determine the degree of threat of stigmatization. See Abington, 374 U.S. at 318 (Stewart, J., dissenting).

67. See, e.g., Engel, 370 U.S. at 431; Abington, 374 U.S. at 288-99 (Brennan, J., concurring).

68. The Court has expressed concern that school children, especially elementary school children, are a peculiarly captive and impressionable audience, in ways that adults are not. See Abington, 374 U.S. at 296-99 (Brennan, J., concurring).

69. See, e.g., Abington, 374 U.S. at 208 n.3 (testimony of plaintiff Schempp) (reluctance of student to exercise excusal prerogative for fear of stigmatization).

70. The Barnette Court did not even consider the possible stigmatization that Jehovah's Witnesses schoolchildren might suffer for refusing to participate in the Pledge of Allegiance at the height of World War II. See Barnette, 319 U.S. 624. 
observed that "[w]hen the power, prestige and financial support of government is placed behind a particular religious belief, the indirect coercive pressure upon religious minorities to conform to the prevailing officially approved religion is plain." ${ }^{\prime \prime 1}$ This coercive impact has been noted most extensively by Justice O'Connor in promulgating her "endorsement test" as a "clarification" of the Court's Lemon test for establishment clause violations. $^{.2}$

The Court and Justice O'Connor are certainly correct that a clear government endorsement of a particular religious viewpoint may subtly coerce religious choices. ${ }^{73}$ Justice O'Connor's analysis paraphrases the Court's Lemon test to ask whether a government action has as either its purpose or effect communication of a message of endorsement. ${ }^{74}$ The difficulty in endorsement analysis, however, is determining what constitutes a coercive endorsement. Whose perceptions of endorsement count? Recognizing the problems inherent in simply adopting the point of view of the government or of a majority of citizens, ${ }^{75}$ Justice O'Connor posits a hypothetical "objective observer," familiar not only with the context of the particular litigative dispute, but also with the historical and doctrinal foundations of the First Amendment. ${ }^{78}$

Justice O'Connor's test is unsatisfactory for a First Amendment analysis based upon coercion. Her reliance upon the objective observer begs the question of what constitutes an endorsement of religion, because she fails to provide standards to guide her observer (or anyone else). ${ }^{77}$ One person's "permissible accommodation" is often another's "unconstitutional endorsement."78 Is this observer, familiar with the background of the First Amendment, a "strict separationist" or a "nonpreferentialist"?79 Strangely, Justice O'Connor, as objective observer, has found that a stat-

71. Engel v. Vitale, 370 U.S. 421, 431 (1962). Despite thus acknowledging the coercion implicit under a New York statute that required teachers to lead vocal classroom prayers composed by the state, the Court implied that such coercion was irrelevant to its holding that the prayers were a statesponsored religious activity in violation of the establishment clause. Id. at 431-33.

72. See Lynch v. Donnelly, 465 U.S. 668, 687-89 (1984) (O'Connor, J., concurring); Wallace v. Jaffree, 472 U.S. 38, 70 (1985) (O'Connor, J., concurring in judgment).

73. The Court has suggested that the relevant inquiry should be "whether the symbolic union of church and state effected by the challenged governmental action is sufficiently likely to be perceived by adherents of the controlling denominations as an endorsement, and by the nonadherents as a disapproval, of their individual religious choices." Grand Rapids School Dist. v. Ball, 473 U.S. 373, 390 (1985).

74. Lynch, 465 U.S. at 687-90 (O'Connor, J., concurring).

75. See Smith, Symbols, Perceptions, and Doctrinal Illusions: Establishment Neutrality and the "No Endorsement" Test, 86 MICH. L. REv. 267, 283-99 (1987).

76. Jaffree, 472 U.S. at 76 . In announcing her endorsement test in Lynch, Justice O'Connor initially suggested that the actual perceptions of real citizens would be decisive. 465 U.S. at 690 (O'Connor, J., concurring).

77. See Smith, supra note 75 , at $292-93$.

78. Compare Estate of Thornton v. Caldor, Inc., 472 U.S. 703, 711-12 (1985) (O'Connor, J., concurring) (statute allowing employees of private business to elect not to work on own "Sabbath" impermissibly endorses religion) with McConnell, Accommodation, supra note 3, at 50-58 (statute struck down in Caldor was a permissible accommodation of the free exercise of religion).

79. McConnell, Accommodation, supra note 3, at 48; see also Marshall, supra note 23, at 537. 
ute providing for a classroom "moment of silence for meditation or voluntary prayer" is an unconstitutional endorsement, ${ }^{80}$ while a municipallyfunded public display of a Christmas nativity scene is not. ${ }^{\mathbf{8 1}}$

If the purpose of the endorsement test is to prevent the government from causing citizens to believe that they are political "outsiders" due to their religious beliefs, as Justice O'Connor would have it, ${ }^{82}$ or, similarly, to prevent citizens from being coerced in their religious choices by the government placing its imprimatur upon certain religious positions, then the relevant perspective for determining endorsement should be the actual perceptions of real citizens. ${ }^{83}$ The intent of the government should be important only to the extent that it influences the manner in which government action is actually perceived by citizens. Therefore, evidence of an intent to endorse religion might serve as a trigger for a more searching inquiry into the actual effects of government acts, rather than as andependent test of constitutionality. ${ }^{84}$

However, to invalidate a government action on the ground that a minority of citizens think it endorses a particular religious position would paralyze the government in many areas. In as pluralistic a society as modern America, many apparently neutral state actions may strike some observers as endorsements of religion. ${ }^{85}$ By recognizing the perceptions of any citizen, the test would risk invalidating practices that are neither intended to endorse nor generally perceived as endorsing religion, but are misperceived as endorsements of religion by a few people.

This problem of governmental paralysis, however, exists only if the sole remedy available to a court is to enjoin the government activity. But if the remedy is narrowly tailored to removing whatever coercive pressure is created, invalidating the entire government activity will not always be neces-

80. Jaffree, 472 U.S. at $67-79$ (O'Connor, J., concurring).

81. Lynch v. Donnelly, 465 U.S. 668, 688-94 (1984) (O'Connor, J., concurring). Justice O'Connor found that the crèche was not religious.

82. See Wallace, 472 U.S. at $69 ;$ Lynch, 465 U.S. at 687-88.

83. See Smith, supre note 75, at 294-95.

84. See Edwards v. Aguillard, 482 U.S. 578, 612-40 (1987) (Scalia, J., dissenting); cf. Paulsen, supra note 3, at 339-45 (suggesting Lemon test should be revised so purpose prong acts as "trigger" for equal protection strict scrutiny).

For example, if a state legislature proclaimed Presbyterianism the official state religion, the message of approval sent to adherents, and of disapproval sent to nonadherents, not to mention the message sent to those deciding whether to adhere, certainly tilts the scales of religious choice. But not all such questions are so simple. Are executive proclamations of days of voluntary prayer coercive? $C f$. Madison, Detached Memoranda, reprinted in JAMEs MADISON ON RELIGIOuS LibERTY 89, 93 (R. Alley ed. 1985) (criticizing proclamation of days of prayer, unless such days are clearly designated as voluntary). Are government efforts to acknowledge the place of religion in American society, such as printing "In God We Trust" on federal currency, or proclaiming "God Save This Honourable Court" at the commencement of judicial proceedings, coercive endorsements of religion? See, e.g., Lynch, 465 U.S. at 676-77 (citing "In God We Trust" as example of government acknowledgement, not endorsement, of religion); Abington School Dist. v. Schempp, 374 U.S. 203, 303 (1963) (Brennan, J., concurring) (use of "In God We Trust" is "interwoven . . . so deeply into the fabric of our civil polity" that it is not an unconstitutional endorsement of religion).

85. See, e.g., United States v. Allen, 760 F.2d 447 (2d Cir. 1985) (rejecting claim that United States military policy establishes "religion of nuclearism"). 
sary, and the problem of paralysis will be reduced. In this manner, the objectives of both Justice O'Connor's test and of a coercion-oriented analysis may be achieved. ${ }^{86}$ If the governmental "message" is ambiguous, a disclaimer may provide a sufficient remedy. Thus, a clearly visible disclaimer of religious intent might remedy the risk of endorsement engendered by a crèche displayed on public property. ${ }^{87}$ An insincere or ineffective disclaimer, such as declaring that a proclamation of Presbyterianism as the official state religion is not intended to constitute an endorsement of that religion, would be an inadequate remedy.

\section{Taxpayer Compulsion}

The most indirect form of coercion recognized by the Supreme Court is compulsory taxpayer support of religion. The Court stated in Everson that "[n]o tax in any amount, large or small, can be levied to support any religious activities or institutions, whatever they may be called, or whatever form they may adopt to teach or practice religion." Cohen, the Court went further to conclude that a taxpayer qua taxpayer has standing to sue under the establishment clause, reading the clause's history to suggest "that religious liberty ultimately would be the victim if government could employ its taxing and spending powers to aid one religion over another or to aid religion in general." ${ }^{389}$ The Supreme Court has not explicitly stated, however, that such taxing and spending directly coerces taxpayers. The Court has spoken less of the receipt of tax monies by religious entities as an infringement of religious liberty than of a constitutional right created by the establishment clause not to have one's tax dollars distributed to religious entities. ${ }^{80}$

The fundamental flaw in the taxpayer compulsion argument results from the failure of the Supreme Court to recognize the differences between the exercise of the taxing and spending power in the eighteenth and in the twentieth centuries. The Court has drawn its arguments about taxpayer standing and establishment clause rights of taxpayers almost entirely from the "three-pence" argument of James Madison's famous $M e-$

86. Indeed, as Professor Smith has suggested, Justice O'Connor's "argument suggests that it is really coercion or unwilling indoctrination that should be the touchstone of constitutionality." Smith, supra note 75, at 304-05 n.147.

87. See, e.g., American Civil Liberties Union of Kentucky v. Wilkinson, 701 F. Supp. 1296 (E.D. Ky. 1988) (requiring visible disclaimer on, and equal access by other religious groups to, manger displayed during Christmas season on grounds of state capitol). The fact that such public property is treated as a "public forum" open to other citizen displays on a content-neutral basis underlines the veracity of the disclaimer. See infra notes $125-34$ and accompanying text.

88. Everson v. Board of Educ., 330 U.S. 1, 16 (1947).

89. 392 U.S. 83, 103-04 (1968) (footnote omitted). See also id. at 114 (Stewart, J., concurring); id. at 115 (Fortas, J., concurring).

90. See Flast, 392 U.S. at 103-04; id. at 114 (Stewart, J., concurring). 
morial and Remonstrance Against Religious Assessments, ${ }^{\text {91 }}$ offering little justification for its position apart from this history. ${ }^{92}$ In employing the Remonstrance to determine the twentieth-century meaning of the establishment clause, the Supreme Court has failed to recognize the crucial differences between eighteenth-century Virginia and the modern welfare state. In the eighteenth century, there were no broad programs of public aid carried on by extensive government bureaucracies and financed by tax revenues collected from the incomes of the citizens at large. Nor was there a conception of such aid as entitlements akin to property rights, of which recipients could not be deprived without due process of law. ${ }^{93}$ To apply Madison's arguments about compulsory contributions to religious institutions in an era of very limited government to today's decisions regarding the distribution of government aid is to "fail[] to come to grips with the depths of Madison's fundamental premises."

A further difficulty with the taxpayer compulsion argument lies in its failure to make clear the manner in which the dissemination to religious entities of money drawn from tax revenues influences the religious choices of taxpayers. Whether such aid is distributed in no way alters a taxpayer's tax obligations. ${ }^{95}$ Since the outcome of any case brought by such a taxpayer in no way changes her tax status, the existence or nonexistence of such expenditures cannot influence the religious choices of such a person as a taxpayer.

The taxpayer compulsion argument fails to distinguish satisfactorily between government taxing and government spending as sources of coer-

91.

Who does not see that the same authority which can establish Christianity, in exclusion of all other Religions, may establish with the same ease any particular sect of Christians, in exclusion of all other Sects? that the same authority which can force a citizen to contribute three pence only of his property for the support of any one establishment, may force him to conform to any other establishment in all cases whatsoever?

Madison, Remonstrance, supra note 36, at 300.

92. The taxpayer compulsion argument presented in Flast $v$. Cohen was premised entirely upon the "three pence" argument of the Remonstrance. 392 U.S. at 103-05. The Remonstrance, as construed in Everson, 330 U.S at 12-16, strongly influenced the taxpayer compulsion arguments advanced in McCullom, 333 U.S. 203, 209-12 (1948), and in Engel, 370 U.S. at 431-32 \& nn.13-16.

93. See Goldberg v. Kelly, 397 U.S. 254 (1970).

94. Paulsen, supra note 3 , at 335 n.110.

95. Justice Harlan made this point in his dissent in Flast:

If this case involved a tax specifically designed for the support of religion, as was the Virginia tax opposed by Madison in his Memorial and Remonstrance, I would agree that taxpayers have rights under the religious clauses of the First Amendment that would permit them standing to challenge the tax's validity in the federal courts. But this is not such a case, and appellants challenge an expenditure, not a tax. Where no such tax is involved, a taxpayer's complaint can consist only of an allegation that public funds have been, or shortly will be, expended for purposes inconsistent with the Constitution. The taxpayer cannot ask the return of any portion of his previous tax payments, cannot prevent the collection of any existing tax debt, and cannot demand an adjudication of the propriety of any particular level of taxation. His tax payments are received for the general purposes of the United States, and are, upon proper receipt, lost in the general revenues.

392 U.S. 83, 128 (Harlan, J., dissenting) (footnote omitted). 
cion; it incorrectly conflates two accurate concerns about religious coercion to create a new conception of compulsion, and then applies this new concept in contexts to which neither of its parts applies. ${ }^{96}$ There can be little doubt that a direct tax levied on a religious activity ${ }^{97}$ or levied explicitly to compel religious exercise ${ }^{98}$ operates to coerce individual choices regarding religion. But these forms of taxation are quite different from a general income tax.

It makes no sense to treat the disbursement of federal funds to religious institutions or individuals as any more coercive to taxpayers than other expenditures of tax monies that taxpayers, for religious or nonreligious reasons, may find objectionable. This is not to say that government taxing or spending cannot coerce religious choice, but such coercion-where it exists-should be analyzed as either a coercive tax on a particular class of persons, ${ }^{98}$ or an unequal distribution of public benefits on the basis of the recipients' or nonrecipients' exercise or nonexercise of religion. ${ }^{100}$

\section{The Class Action Component}

The establishment clause protects diffuse, widespread, and individually minimal interests in much the same way that the modern class action device aggregates diffuse and individually minimal interests in, for example, a consumer class action against a business enterprise. ${ }^{101}$ This is not to suggest that the framers self-consciously intended the establishment clause to create a provision analogous to a free exercise case brought as a modern class action; they could not have done so, for the concept of group litigation had not yet appeared in American legal thought.

The First Amendment was framed prior to the "industrialization of group litigation" in the nineteenth century ${ }^{102}$ At that time, the English common law of class actions reflected a different world from that of the modern class action. From its medieval origins through the eighteenth century, group litigation was a creation of equity that merely facilitated

96. The Supreme Court has not directly addressed the problem of taxpayer compulsion in the free exercise context. In the most analogous case, the Court rejected a free exercise challenge by an Amish employer seeking an exemption from social security taxes that violated his religious beliefs. The Court assumed arguendo that the payment of such taxes did burden the free exercise of the plaintiffs religion, and found the state interest in maintaining a sound tax system to be so compelling as to justify such a burden. United States v. Lee, 455 U.S. 252, 259-60 (1982).

97. See, e.g., Murdock v. Pennsylvania, 319 U.S. 105 (1943).

98. This was the harm of revolutionary Virginia's general assessment bill against which Madison's Remonstrance was directed. The assessment bill, which would have allowed the taxpayer to specify to which denomination he wished to have his contribution go, was in effect a compelled tithe. See T. CuRry, supra note 36, at 140-41. Had there been no disbursement of the taxpayer's "three pence" to the religious teacher of his choice, the taxpayer would not have paid this "three pence" at all.

99. See, e.g., Murdock v. Pennsylvania, 319 U.S. 105 (1943).

100. See supra notes 59-64 and accompanying text.

101. See, e.g., Vasquez v. Superior Court, 4 Cal. 3d 800, 484 P.2d 964 (1971).

102. Yeazell, From Group Litigation to Class Action, Part I: The Industrialization of Group Litigation, 27 UCLA L. REv. 514 (1980). 
legal action that cohesive social groups would in any case have attempted (such as efforts by tenants to resolve disputes with lords about manorial duties). ${ }^{103}$ The cohesive nature of the groups involved, and the role of courts of equity in resolving these disputes (which were primarily about customary law), made group litigation at that time more nearly legislation than modern litigation, with relief granted primarily prospectively rather than retrospectively. ${ }^{104}$ The essential concept of litigative representation of the interests of a class of individuals not named as parties to a suit had not yet developed.

The English common law of group litigation did not appear in the United States legal system until the 1820's, when Justice Joseph Story invoked English group litigation precedents in several opinions and in his two equity treatises. ${ }^{105}$ The concept of the class action underwent a slow and tortuous evolution in America until its flowering in the mid-twentieth century. ${ }^{108}$ Obviously, if the concept of group representative litigation was not remotely evident in American law until 1820, it is unlikely to have influenced the framers of the establishment clause. To the extent that the establishment clause is concerned with the protection of religious liberty and not with federalism issues, it embodies the Framers' intuitive notions about the ways in which government can subtly infringe religious liberty by placing diffuse burdens upon the free exercise of religion.

\section{Implications of a FreE Exercise-Cilass Action Approach}

The possibility that the establishment clause exists to aggregate widespread minimal injuries to religious liberty suggests that several conceptual elements of existing establishment clause jurisprudence might also be reexamined.

\section{A. Standing to Sue}

A taxpayer as taxpayer generally does not have standing to challenge allegedly unconstitutional government conduct. ${ }^{107}$ To have standing, a plaintiff must have suffered actual injury as a result of the defendant's conduct, as distinct from injury to an interest shared by plaintiff and a substantial portion of the public at large. ${ }^{108}$ In Flast $v$. Cohen, ${ }^{109}$ the Su-

103. Id. at $516-19$.

104. See Yeazell, Group Litigation and Social Context: Toward a History of the Class Action, 77 Colum. L. REv. 866, 876-74 (1977) [hereinafter Yeazell, Social Context]; Yeazell, From Group Litigation to Class Action, Part II: Interest, Class, and Representation, 27 UCLA L. REv. 1067 (1980).

105. See S. Yeazell, From Medieval Group litigation to the Modern Class action 214-19 (1987).

106. Id. at $220-37$.

107. See Frothingham v. Mellon, 262 U.S. 447 (1923).

108. See Warth v. Seldin, 422 U.S. 490, 498-99 (1975). In a class action suit, the named plaintiff must satisfy the requirements of individual standing. See Simon v. Eastern Ky. Welfare Rights Org., 
preme Court created an exception to this rule. The Court permitted a taxpayer to sue the government for violations of the establishment clause upon showing, first, that the government activity was an exercise of the congressional taxing and spending power of Article I of the Constitution, and, second, that the challenged enactment exceeded specific constitutional limitations on the exercise of the taxing and spending power, rather than merely exceeding the powers delegated to Congress by the Constitution. ${ }^{110}$ The Flast exception was justified on the basis of the establishment clause's assertedly unique history, which the Court interpreted as demonstrating that the clause is a specific limitation on the taxing and spending power. ${ }^{111}$ The unique status of the Flast exception is demonstrated by the Gourt's unwillingness to expand the exception to cover other types of constitutional violations. ${ }^{112}$

The Court in Flast sought to afford remedies for diffuse injuries to religious liberty. It could have seized upon the concept of a class action in free exercise/establishment clause cases; taxpayer standing is a poor proxy for what is actually at stake. A free exercise-class action analogy acknowledges that establishment clause violations involve actual injury, yet maintains continuity with general standing doctrine. The test for determining standing should not be the nexus between taxpayer status and specific constitutional limitations on congressional spending enunciated in Flast; rather, it should be the usual determination of whether plaintiff has suffered an injury as a result of defendant's conduct such that granting relief will remedy plaintiff's injury. ${ }^{113}$ The injury is to an individual's religious liberty, a personal stake often undervalued because it is diffuse, inchoate, and non-economic. ${ }^{114}$ When a plaintiff can allege injury to her religious liberty interests, she should have standing. ${ }^{116}$ Since "[o]rdinarily, one may not claim standing . . . to vindicate the constitutional rights of some third

426 U.S. 26, 40 (1976); Huddleston v. Duckworth, 97 F.R.D. 512 (N.D. Ind. 1983).

109. 392 U.S. 83 (1968).

110. Flast, 392 U.S. at $102-03$.

111. Id. at 88-100. See supra notes 83-95 and accompanying text.

112. See, e.g., Valley Forge Christian College v. Americans United for Separation of Church \& State, 454 U.S. 464 (1982) (rejecting citizen and taxpayer standing to mount establishment clause challenge to administrative action under Article IV $\$ 3$ of Constitution); Schlesinger v. Reservists' Committee to Stop the War, 418 U.S. 208 (1974) (rejecting citizen and taxpayer standing under Article I, $\S 6$ of Constitution); United States v. Richardson, 418 U.S. 166 (1974) (rejecting citizen and taxpayer standing under Article I, $\S 9$ of Constitution).

113. See, e.g., Harris v. White, 479 F. Supp. 996, 1007 (D. Mass. 1979) (collecting cases). Cf. Abington School Dist. v. Schempp, 374 U.S. 203, 266 n.30 (1963) (Brennan, J., concurring) (free exercise claims of parents in Zorach, McCollum, and Schempp were sufficient allegations of injury to religious liberty to confer standing).

114. Cf. McGowan v. Maryland, 366 U.S. $420,429-430$ (1961) (standing to challenge state action under establishment clause does not require proof that particular religious freedoms are infringed).

115. Such an injury must be felt directly by the plaintiff. Sierra Club v. Morton, 405 U.S. 727, 734-40 (1972). 
party,"116 in cases in which the plaintiff was unable to allege such personal injury there should be no standing.

\section{B. Remedial Possibilities}

Because the paradigmatic modern free exercise suit is ordinarily brought by a plaintiff claiming that a facially neutral rule burdens the free exercise of her religion, ${ }^{117}$ the standard remedy is to grant the plaintiff an individual exemption from the requirement. ${ }^{118}$ For a violation of the establishment clause, on the other hand, the customary relief is to enjoin the offending government conduct. ${ }^{119}$ These remedies are not explicitly required by these clauses; rather, they are functional responses to the harms to be remedied. Free exercise clause plaintiffs have occasionally sought money damages; ${ }^{120}$ similarly, if a law on its face prohibits the free exercise of religion, or applies only to persons who would be entitled to an exemption, the entire law may be invalidated on free exercise grounds. ${ }^{121}$ This range of potential free exercise clause remedies suggests that courts should enjoy a degree of remedial flexibility unavailable under current establishment clause doctrine.

The remedial starting point should be that employed under the free exercise clause: granting individual exemptions to all those within the class represented by an objecting plaintiff. In some instances, though, an exemption, however widespread, will be insufficient. Exercising the option to opt out may stigmatize dissenters, unless the alternatives available upon excusal are reasonably attractive. ${ }^{122}$ Moreover, an exemption is often an inappropriate remedy for government endorsement. ${ }^{123}$ In such cases, other

116. Barrows v. Jackson, 346 U.S. 249, 255 (1953); accord Singleton v. Wulff, 428 U.S. 106, 114 (1976).

117. See, e.g., Hobbie v. Unemployment Appeals Comm'n, 480 U.S. 136 (1987) (free exercise challenge to denial of unemployment benefits); Bowen v. Roy, 476 U.S. 693 (1986) (free exercise challenge to requiring provision of social security number as condition of receiving government benefits); Thomas v. Review Bd., 450 U.S. 707 (1981) (free exercise challenge to unemployment commission's determination that dismissal for refusal to engage in conduct objectionable to religious beliefs does not constitute "good cause").

118. See, e.g., Thomas, 450 U.S. at 720.

119. See, e.g., Wallace v. Jaffree, 472 U.S. 38 (1985) (invalidating law providing for moment of silence for voluntary prayer or mediation at start of public school day); McCollum v. Board of Educ., 333 U.S. 203 (1948) (enjoining program of religious instruction on public school premises); see also Smith, supra note 23 , at 298 n.126.

120. See, e.g., Mozert v. Hawkins County Pub. Schools, 647 F. Supp. 1194 (E.D. Tenn. 1986) (rejecting free exercise suit for monetary damages and exemption from use of public school textbooks considered religiously objectionable).

121. See, e.g, McDaniel v. Paty, 435 U.S. 618 (1978) (law disqualifying ministers from serving as delegates to state constitutional convention violates free exercise clause; entire law held invalid).

122. See supra notes $65-70$ and accompanying text. This is not to suggest that all opt-out provisions necessarily result in such stigmatization. If attractive alternatives to participation are available, the threat of stigmatization should be largely obviated. See Abington School Dist. v. Schempp, 374 U.S. 203, 318 (1963) (Stewart, J., dissenting).

123. For example, it is not possible for a citizen to opt out of a nativity scene or a proclamation of an official state religion. 
forms of relief are appropriate. If less drastic remedies are insufficient to rectify the harm, a court should enjoin the challenged conduct. ${ }^{\mathbf{1 2 4}}$

Cases involving the distribution of public benefits to religious entities offer a further remedial option. ${ }^{125}$ In such cases, the failure to confer the benefit in question upon a similarly situated individual or organization on the basis of religion would constitute a burden on free exercise. ${ }^{126}$ In theory, the entities involved would be "exempted" from the religious requirements for the aid. In practice, a court might employ a "second-look" doctrine $^{127}$ to neutralize such "coercion through discrimination" by requiring that the benefit payment include all those improperly excluded, while leaving the legislature the option of discontinuing the entire program. ${ }^{28}$

A residual form of coercion is that engendered by government endorsement of a particular religious position. Cases involving religious expression by the state, such as the presentation of religious symbols, rituals, or activities on government property or in government activities, most frequently raise the specter of endorsement. ${ }^{129}$ In such cases, two remedial

124. In certain instances, an opt-out solution will be inappropriate. On the one hand, the state's interest in the challenged activity may be so compelling that to grant an exemption would substantially undermine the state interest. See, e.g., United States v. Lee, 455 U.S. 252 (1982) (denying Amish request for religious exemption from social security tax system). On the other hand, the state action may be such that continuing it while permitting persons to opt out would not eliminate religious coercion. Such was probably the case in Engel $v$. Vitale: a state-composed prayer can hardly fail to constitute an endorsement of religion. 370 U.S. 421, 425, 430-31 (1962) (enjoining recitation of prayer at start of public school day). In such a case, the state action should be enjoined.

125. Despite the abundance of such cases, no clear principle for distinguishing permissible from impermissible aid has emerged from the Court's opinions. See Wallace v. Jaffree, 472 U.S. 38, 108-12 (1985) (Rehnquist, J., dissenting). Indeed, the Justices themselves have shown great disagreement on the subject. See, e.g., Wolman v. Walter, 433 U.S. 229 (1977) (six separate opinions filed).

126. See McConnell, Coercion, supra note 3. See also supra note 46 and accompanying text.

127. Cf. Railway Express Agency v. New York, 336 U.S. 106, 112 (1949) (Jackson, J., concurring) (invalidating law under equal protection clause, unlike other provisions, "does not disable any governmental body from dealing with the subject at hand"); G. CALABRESI, A COMMON LAw FOR THE AGE OF STATUTES (1983) (suggesting courts should employ "second-look" doctrines to force legislatures to reconsider obsolescent statutes).

128. See, e.g., Califano v. Goldfarb, 430 U.S. 199 (1977). Such an outcome is similar to that in Widmar v. Vincent, 454 U.S. 263 (1981), a hybrid free exercise-free speech case in which the Court ruled that a public university that allowed organized student groups use of university facilities for their activities could not deny such use to a student religious group simply because the group was religious. The university could either allow the religious group to use the facilities on the same basis and under the same conditions as other student groups or not allow access to any student groups.

Aguilar v. Felton, 473 U.S. 402 (1984), provides an example of a recent case in which this approach would have altered the outcome. In Aguilar, the Supreme Court upheld a taxpayer challenge to the use of federal funds to pay public employees teaching remedial skills to educationally-deprived children in parochial schools, finding that the mechanisms designed to ensure that the public school employees would not advance the schools' religious mission had created "excessive entanglement" between church and state. Since the remedial education program applied to non-parochial private schools as well as to parochial schools, and since similar remedial education was available in the public schools, supporting such remedial aid in parochial schools could not coerce or alter religious choices of students or parents. Thus, the aid should have been constitutionally permissible. See 473 U.S. at 430-31 (O'Connor, J., dissenting).

129. In two such cases the Supreme Court has shown reluctance to apply its Lemon test. See Lynch v. Donnelly, 465 U.S. 668 (1984) (upholding public crèche display); Marsh v. Chambers, 463 U.S. 783 (1983) (upholding religious invocation in state legislature, on basis of use of legislative invocation in first Congress). 
concerns should be addressed. First, a court should remedy the coercive pressure created by unequal distribution of the symbolic benefit conferred by the government expression by requiring that equal access be provided to those previously excluded. ${ }^{130}$ Since equal access may in some instances be practically impossible, the expression might be enjoined in such cases. Second, a court should carefully investigate whether a government action places the state's imprimatur upon a particular religious position. ${ }^{131}$ If so, a court should require an official disclaimer of intent to endorse. If nonadherents of the allegedly endorsed religious position have equal access to the state's expressive medium as adherents do, a disclaimer should be a sufficient remedy. ${ }^{132}$

If the crux of an establishment clause violation is state interference with religious liberty, ${ }^{133}$ then relief from such wrongs should restore that liberty to the injured parties. The appropriate remedies should be: (1) removing any government compulsion by making the compelled conduct strictly voluntary, and creating a non-stigmatizing opt-out mechanism for conscientious objectors; (2) neutralizing coercion through discrimination by extending the right or benefit in question to the disfavored class, on equivalent terms; or (3) eliminating coercion through endorsement by requiring a sincere and effective official disclaimer of intent to endorse and by providing equal access to the government expressive medium on a nonreligious basis. If such measures are inadequate to remedy the harm to religious liberty, a court should enjoin the entire program or activity. ${ }^{\mathbf{1 3 4}}$

130. Such a remedy corresponds to the Supreme Court's general approach to cases involving private expressive use of public property, usually referred to as "public forum doctrine." See Perry Educ. Ass'n v. Perry Local Educators' Ass'n, 460 U.S. 37 (1983); Heffron v. International Soc'y for Krishna Consciousness, 452 U.S. 640 (1981).

In fact, this is precisely what the Second Circuit did in resolving an establishment clause challenge to a crèche display, relying upon public forum doctrine to justify its remedy. McCreary v. Stone, 739 F.2d 716, 727-28 (2d Cir. 1984), affd mem. by equally divided Court sub nom. Board of Trustees v. McCreary, 471 U.S. 1849 (1985) (public forum doctrine requires equal access to crèche site).

131. See supra notes 71-87 and accompanying text.

132. Although such government expression may be permissible as a matter of constitutional law, affording truly equal access on neutral terms to the many diverse religious perspectives existing in modern American society may be so difficult as to be for all practical purposes impossible.

133. See supra notes $36-40$ and accompanying text. This Note assumes that the decision not to exercise a religion is simply a special case of the free exercise of religion protected by the First Amendment. See Paulsen, supra note 3, at 337-38 n.116. But cf. Freeman, The Misguided Search for the Constitutional Definition of "Religion", 71 Geo. L.J. 1519, 1522 (1983) ("What the free exercise clause protects is the free exercise of religion, not the free exercise of conscience.").

134. Compare West Virginia State Bd. of Educ. v. Barnette, 319 U.S. 624 (1943) (compulsory flag salute violates constitutional rights of Jehovah's Witnesses students; students exempted) with McCollum v. Board of Educ., 333 U.S. 203 (1948) ("released time" program for consenting students to receive religious instruction on public school premises, with nonparticipating students sent to study hall, violates establishment clause; program enjoined). Both cases involved religious coercion, including the danger of stigmatization. And in both, the state was found to be acting beyond its legitimate authority. Yet the Supreme Court enjoined the McCollum program and granted an exemption to the Witnesses in Barnette. 


\section{CONCLUSION}

Reconceptualizing establishment clause suits as free exercise class actions provides a useful analytic tool for evaluating the Supreme Court's establishment clause jurisprudence. It focuses upon the key concern underlying both the establishment and free exercise clauses: the protection of religious liberty. But it does so with the explicit recognition that government actions may impose subtle, difficult-to-recognize burdens upon the religious choices of many individuals. Furthermore, this reconceptualization offers a view of standing to sue more in line with the Court's general standing doctrine than is the "taxpayer exception" of Flast $v$. Cohen. ${ }^{135}$ Finally, the free exercise-class action approach provides a new perspective upon establishment clause remedial options and restores a basic symmetry between remedies under the two religion clauses. ${ }^{136}$ Free exercise claims, which are typically individual cases, systematically understate the true costs of accommodating religious beliefs in that they do not fully consider the effect of granting the same relief to other, similarly-situated potential claimants. ${ }^{137}$ By thinking of these cases on a class, rather than atomistic, basis courts may fashion their remedies with a more accurate appreciation of the consequences. ${ }^{138}$ Conversely, establishment clause claims tend to overstate the extent of the constitutional violation and resulting harm. ${ }^{139}$

The class action came into being only through religious actions, as the earliest recorded English class actions were brought to enforce the tithe obligations of a "class" of defendant parishioners. ${ }^{140}$ Perhaps it is fitting that the modern class action should afford the best analogy for understanding the manner in which the establishment of religion clause operates to protect religious liberty.

135. 392 U.S. 83 (1968).

136. The free exercise-class action approach may also restore some of the initial federalistic orientation of the establishment clause, as it permits the maximum possible degree of community selfdetermination by limiting judicial intervention with the decisions of other segments of government to the minimum necessary for the full protection of religious liberty.

137. For example, were the exception from compulsory education laws allowed in Wisconsin $v$. Yoder, 406 U.S. 205 (1972), consistently applied, the effect upon public education would be substantial. Cf. Mozert v. Hawkins County Bd. of Educ., 827 F.2d 1058, 1072-73 (6th Cir. 1987) (Kennedy, J., concurring), cert. denied, 108 S. Ct. 1029 (1988) (noting negative impact on public school reading curriculum of allowing widespread exemptions).

138. Cf. Goldman v. Weinberger, 475 U.S. 503, 524 (1986) (Blackmun, J., dissenting) (government may consider costs of allowing exemptions to all potential claimants in deciding whether to exempt plaintiff from military headgear requirement).

139. Cf. Swann v. Charlotte-Mecklenburg Bd. of Educ., 402 U.S. 1, 16 (1971) (federal courts must tailor scope of judicial remedy to fit nature and extent of constitutional violation).

140. See Yeazell, Social Context, supra note 104, at 869-96. 
